\title{
Vigorous attempts to Boost and buoying up MSMEs in India
}

\author{
Dr.Venkateswararao.Podile ${ }^{1}$, Siva Sree.Chinta ${ }^{2,}$ Prof.D.SuryachandraRao ${ }^{3}$ \\ ${ }^{I}$ (Professor, MBA Department, Andhra Loyola Institute of Engineering and Technology, India' \\ 2(Research Scholar, Department of Business Management, Krishna University, India) \\ 3(Professor, Department of Business Management, Krishna University, India)
}

\begin{abstract}
In India, after agriculture, small business is the second largest employer of human resources. MSMEs constitute more than 80 percent of the total number of industrial enterprises and support industrial development, 40 per cent of industrial output, 80 per cent of employment in the industrial sector, 45 per cent of value added by the manufacturing sector and 40 per cent of total exports. In this paper an attempt is made to explain various schemes implemented by Ministry of Micro, Small and Medium Enterprises, Government of India for the promotion of MSMEs in India including general schemes, schemes for Khadi and Village Industries Sector, schemes for Coir Sector and schemes implemented by MSME Development Commissioner.
\end{abstract}

Key words: MSMEs, khadi industries, Village industries, coir board, promotional schemes

\section{Introduction}

MSME sector is one of the most crucial sectors of Indian economy as far as the number of employments generated. As more than 65 Percent of Indian population lives in rural and semi-rural areas, small business became a major source of income for many residing in these areas. After agriculture, small business in India is the second largest employer of human resources. In India, MSMEs constitute more than 80 percent of the total number of industrial enterprises and support industrial development, 40 per cent of industrial output, 80 per cent of employment in the industrial sector, 45 per cent of value added by the manufacturing sector and 40 per cent of total exports. Their contribution to the Indian GDP is $8 \%$ and the sector has registered growth rate of 10.8\%. Micro, small and medium enterprises as per MSMED Act, 2006 are defined based on their investment in plant and machinery for manufacturing enterprise and on equipment for enterprises providing or rendering services.

\begin{tabular}{|l|l|l|}
\hline Type of enterprise & $\begin{array}{l}\text { Manufacturing enterprises } \\
\text { (Investment limit in plant and machinery) }\end{array}$ & $\begin{array}{l}\text { Service enterprises } \\
\text { (Investment limit in Equipment) }\end{array}$ \\
\hline Micro enterprise & Rs. 2.5 million / Rs. 25 lakh & Rs. 1 million / Rs. 10 lakh \\
\hline Small enterprise & Rs.50 million / Rs. 5 crore & Rs. 20 million / Rs 2 crore \\
\hline Medium enterprise & Rs 100 million / Rs 10 crore & Rs. 50 million / Rs 5 crore \\
\hline
\end{tabular}

\section{Review Of Literature}

Venugopal $(1993)^{1}$ found that the government organizations' performances, which were set up for promoting village and cottage industries, are below the level of expectations. Cecile Carpenter and Jean Marc Suret $(2005)^{2}$ reviewed the taxation policy introduced by the government for the progress of the MSME sector. They suggested that there is an urgent need to introduce more result-oriented measures; if not tax incentive initiatives will remain ineffective. Jogendra Kumar Nayak et al $(2006)^{3}$ studied the perceptions of mangers regarding the reasons for outsourcing and the impact of outsourcing in small and medium enterprises. Prof. B.Appa Rao $(2007)^{4}$ conducted a survey on policy framework of SMEs sector. He found that the incentives that are offered by the selected countries towards promotion of SMEs are mainly in the form of tax reliefs, subsidies, soft credit facilities, preferential treatment in government policies etc. T. Gopi (2009) $)^{5}$ studied the promotional policy measures for the development of small entrepreneurs from time to time. Anthony K. Ahiawodzi and Thomas C. Adade (2012) ${ }^{6}$ had developed an econometric model to examine the impact of various factors on the development of the MSME sector. They found that access to credit is the most dominant factor in case of firm's overall development. Bhoomika Garg (2014) ${ }^{7}$ has studied the challenges that the Indian MSME sector is facing along with the government policy considerations. Ashu Katyal and Betsy Xaviour (2015) ${ }^{8}$ expressed the view that MSME sector has greater role for the overall economic development in India. They also said that MSMEs have the capacity to absorb low skilled workers who are otherwise left unemployed. It is concluded that there was no study which dealt comprehensively with the schemes introduced in India for the development of MSMEs. 


\section{Objectives}

The main objective is to present the schemes introduced and implemented to promote MSMEs in India. The specific objectives are the following.

1. To examine the general schemes introduced by ministry of Micro, Small and Medium Enterprises, Government of India for the promotion of MSMEs in India.

2. To list out the schemes being implemented for Khadi and Village Industries Sector.

3. To describe the schemes relating to coir sector.

4. To present the schemes being implemented by MSME Development Commissioner

\section{Methodology}

The present study is a descriptive study. An attempt is made to review the existing literature on MSMEs in India. After extensive survey of the literature it is found that there was no specific study which dealt with schemes for boosting and buoying up MSMEs in India. In this paper an attempt is made to review various schemes introduced to promote MSMEs in India. The schemes are broadly covered under the headings of A) General schemes, B) Schemes for Khadi and Village Industries Sector, C) Schemes for Coir Sector and D) Schemes implemented by MSME Development Commissioner.

\section{A. General schemes}

\section{Schemes Introduced To Boost And Buoying Up Msmes In India}

\section{Marketing Assistance Scheme}

This scheme is being implemented by the ministry of Micro, Small and Medium Enterprises through National Small Industries Corporation Limited (NSIC). This scheme is introduced with the objectives of enhancing the marketing competitiveness of MSMEs, providing them a platform for interaction with the individual or institutional buyers, updating them with prevalent market scenario and to provide them a form for redressing their problems.

\section{International Cooperation (IC) Scheme}

Under this scheme assistance is given to Indian MSMEs to infuse, to upgrade technology, to modernize and promote their exports. Activities in the scheme include 1.deputation of business delegations to other countries to explore new areas of technology infusion or up gradation, facilitating foreign collaborations and improving markets for MSMEs 2. Providing support to MSMEs in participating in international exhibitions and trade fairs 3. providing assistance for organizing seminars and conferences on themes of MSMEs.

\section{Performance and Credit Rating Scheme}

This scheme is being implemented by NSIC. Through this scheme financial assistance is provided to MSMEs for getting credit rating by the agencies like CRISIL, ICRA and CARE.

\section{Assistance to Training Institutions Scheme}

This scheme provides financial assistance for strengthening the infrastructure of the existing Entrepreneurship Development Institutes, for establishing of new Entrepreneurship Development institutions and for supporting entrepreneurship and skill development activities. The assistance is provided in the form of capital grant.

\section{Survey, Studies and Policy Research Scheme}

This scheme provides financial support for collecting regular and periodical data on various aspects of MSMEs in India. The scheme also provides financial support to study and analyze the constraints and challenges as well as opportunities faced by MSMEs. This scheme also helps to use the surveys and studies for policy research.

\section{A Scheme for Promoting Innovation and Rural Entrepreneurship (ASPIRE)}

This scheme was launched by the ministry of Micro, Small and Medium Enterprises on 18.3.2015. The main objective of the scheme is to set up a network of technology centers and incubation centers to accelerate entrepreneurship and also to promote start-ups for innovation and entrepreneurship in agro-industry. The important components are to set up Livelihood Business Incubators (LBI), Technology Business Incubators (TBI) and to create a framework for start-up promotion through Small Industries Development Bank of India (SIDBI).

\section{B. Schemes for Khadi and Village Industries Sector}

Prime Minister's Employment Generation Programme (PMEGP)

This is a credit linked subsidy scheme. This scheme is implemented by the of the ministry of Micro, Small and Medium Enterprises through KVIC, DICs and State KVI Boards with KVIC by setting up new self-employment 
ventures or projects or micro enterprises to generate employment opportunities in rural and urban areas of the country. The idea is to bring together widely dispersed traditional artisans or rural and urban unemployed youth and give them self employment opportunities.

\section{Scheme of fund for Regeneration of Traditional Industries (SFURTI)}

This scheme was introduced with the objective of making the traditional industries more productive and competitive and facilitating their sustainable development. This objective is achieved by creating a fund for regeneration of traditional industries and by organizing the traditional industries and artisans into clusters.

\section{Market Promotion and Development Assistance (MPDA)}

The MDA scheme of KVIC was modified as Market Promotion Development Assistance scheme (MPDA). This scheme is formulated by merging different schemes and sub-schemes including Market Development Assistance, Publicity, Marketing and Market promotion and adds a new component of Infrastructure including Marketing complexes or Khadi Plaza.

\section{Schemes for Coir Sector}

Coir Vikas Yojana

Under this scheme coir board adopted strategic and aggressive product specific and market specific promotional programmes for popularizing coir and coir products in markets abroad. Through this scheme assistance is provided for the entrepreneurs in coir industry to participate in international fairs, product promotion programmes and seminars.

\section{Coir Udyami Yojana}

Under this scheme, Government provides assistance to replace the outdated rats and looms. Assistance is also provided to spinners and tiny household units for constructing work sheds to increase production and earnings of workers. The main goal of the scheme is to provide assistance for rejuvenating, modernizing and technologically upgrading spinners and tiny household sector.

\section{Coir S \& T Yojana}

This scheme is also known as 'Science and Technology Scheme'. This scheme is being implemented by the coir board with the help of Central Coir Research Institute, Kalavoor and the Central Institute of Coir Technology, Bangalore. With the help these research institutions; the Board is developing many new ecofriendly technologies, processes, diversified products, equipments and machinery for increased productivity and efficiency of the coir products.

\section{D) Schemes implemented by MSME Development Commissioner Credit Guarantee Scheme (CGTMSE)}

This scheme was introduced to strengthen credit delivery system and facilitate flow of credit to the MSE sector. Through this scheme, loans up to Rs. 100 lakh without collateral and third party guarantees are being provided to SMEs. Under this scheme, the Government reassures the lender that, in the event of a MSE unit fails to discharge its liabilities to the lender; the CGTMSE would make good the loss incurred by the lender.

\section{Credit Linked Capital Subsidy Scheme (CLCSS)}

This scheme is being implemented to facilitate technological up gradation by new and existing Micro and Small Enterprises (MSEs) engaged in manufacturing. Through this scheme, 15percent upfront capital subsidy to a maximum limit of Rs.15.00 lakhs is given to MSEs for induction of well-established and improved technologies. This scheme covers 51 sub-sectors or products with approved machinery and technologies.

\section{Micro and Small Enterprises Cluster Development Programme (MSE-CDP)}

This scheme was introduced by the ministry of Micro, Small and Medium Enterprises for enhancing the productivity and competitiveness as well as capacity building of Micro and Small Enterprises (MSEs) and their collectives in the country. As per the scheme the cluster is defined as a group of enterprises located within an identifiable and as far as practicable, contiguous area and producing same or similar products or services. The objectives of the scheme include providing support for sustainability and growth of MSEs by addressing common issues, building capacity of MSEs for common supportive action through formation of self help groups, consortia, up gradation of associations, etc. and to common facility centers. 


\section{Lean Manufacturing scheme}

This scheme was introduced to enhance the manufacturing competitiveness of MSMEs through the application of various Lean Manufacturing (LM) techniques like 5S system, visual control, standard operating procedures (SOPs), Just in Time (JIT),KANBAN System, Cellular Layout, Value Stream Mapping, Single Minutes Exchange of Dies (SMED), and Total Productive Maintenance.

\section{Financial Design Clinic Scheme}

This scheme was introduced to create a sustainable design eco system for the MSME sector through continuous learning and skill development.

\section{Information and Communication Technology scheme}

This scheme was introduced to promote an echo system of cost effective and all inclusive ICT applications for MSMEs through Cloud Computing. In this scheme, to encourage MSMEs to use Cloud Computing for ICT applications, the Government provides subsidy for user charges for a period of 3 years. The idea is that the benefits accrued through implementing ICT for subsidy period in their enterprises will motivate MSMEs to continue to use the ICT application with their own expenses after this period.

\section{Intellectual Property Rights scheme}

This scheme was introduced to enhance awareness of MSMEs about Intellectual Property Rights (IPRs), to take measures for the protecting their ideas and business strategies, to assist SMEs in technology upgradation and enhancing competitiveness and for effective Utilization of IPR tools by MSMEs and to sensitize Entrepreneurs on IPR related matters by providing financial assistance for taking up the identified initiatives.

\section{Incubation scheme}

Under this scheme the Government is providing opportunity to the innovators in developing and nurturing their new innovative ideas for the production of new innovative products which can be sent in to the market for commercialization. This Ministry has been implementing this scheme since 2008. Financial support is given through the business incubator (BIs). The BIs may be engineering colleges approved by AICTE, central or state universities recognized by UGC and other recognized institutions.

\section{Bar Code Scheme}

This scheme was introduced to enhance marketing competitiveness of Micro and Small Enterprises (MSEs) by popularizing the adoption of bar codes, motivating and encouraging MSEs for use of bar codes through conducting seminars. Some financial assistance is also provided in the form of reimbursing 75 percent of one time registration fee.

\section{Marketing Development Assistance (MDA) Scheme}

This scheme was introduced with the objectives of encouraging small and micro enterprises in tapping and developing overseas markets, increasing participation of representatives of small and micro manufacturing enterprises under MSME India stall at international trade fairs and exhibitions and to enhance exports from the small and micro manufacturing enterprises.

\section{ZED Maturity Model: Quality Management Standards (QMS) and Quality Technology Tools (QTT)} scheme

The main activities of the scheme include conducting one day awareness campaign, two days workshop at Metros, one National level workshop at Delhi, implementation of Quality Management Standards (QMS) and Quality Technology Tools (QTT) in selected MSEs Cluster through various expert agencies or organizations.

\section{Trade Related Entrepreneurship Assistance and Development (TREAD) for Women}

The main objective of the scheme is to empower women through trade related training, information and counseling extension activities related to MSME trades, products, services and so on. As per this scheme financial loans are provided through NGO's who are also provided Government of India grant for capacity building. The Assistance is provided for self-employment ventures by women for pursuing different nonfarm activities.

Public Procurement Policy Vendor Development Programme

This scheme was introduced to create and enhance marketing linkages between Indian SMEs and Public Sector Units like BEL, BHEL, TELCO, BSNL and IOC for their mutual benefit. 
Marketing Assistance and Technology Up-gradation (MATU) scheme

This scheme is useful for MSMEs for enhancing competitiveness in national and international markets by adopting better packaging technologies, modern marketing strategies and encouraging them to acquire ISO certification and Bar Codes for making their products more acceptable to the consumers.

\section{Technology Centre Systems Programme}

The main objective of the scheme is making MSMEs globally competitive through access to advanced manufacturing technologies.

\section{Technology and Quality up gradation Support to MSMEs}

This scheme was introduced to encourage the MSMEs to acquire product certification or licenses from National and International bodies and adopt other technologies mandated as per the global standards.

\section{Conclusion}

Various policies and schemes are being implemented by Ministry of Micro, Small and Medium Enterprises, Government of India for promoting MSMEs in India. Schemes are being modified and up dated from time to time. Most of the schemes provide financial support for MSMEs to market their products, to update their technologies and to become more competitive. No doubt, Indian MSMEs are getting boosted up and Buoying up through these vigorous attempts. Further research is required for examining the impact of these schemes.

[1]. Venugopal S, A study of village and cottage industries in Kerala: problems and prospects-school of management studies, Cochin University, 1993.

[2]. Cecile Carpenter \& Jean Marc Suret, On the Usefulness of Tax Incentives for Business Angels \& SME Owners: An Empirical Analysis, ISSN No. 1198 - 8177, Scientific Series, 2005.

[3]. Jogendra Kumar Nayak et al, "The determinants and impact of outsourcing on SME- An empirical study", IIMB Management Review, Vol:19, No.3, , 2006, pp.277-284.

[4]. Prof. B.Appa Rao, "SME sector: policy framework: Global Experience", NIST Journal of Management", Vol.1, No.1, 2007, pp.1927.

[5]. T. Gopi, "Promotion of small entrepreneurship in AP- A comparative study", Finance India, Vol.XXIII, No.1, 2009, pp.199-209.

[6]. Anthony K. Ahiawodzi \& Thomas C. Adade, "Access to Credit \& Growth of Small \& Medium Scale Enterprises in the Ho Municipality of Ghana", British Journal of Economics, Finance \& Management Sciences, ISSN No. 2048 - 125X, Vol. 6, No. 2, 2012, pp $34-51$.

[7]. Bhoomika Garg, Role of MSMEs in Economic Development, Research journal of Entrepreneurship, Vol. 2, No. 2, February, 2014, pp $1-8$.

[8]. Ashu Katyal \& Mrs. Betsy Xaviour, A Study on MSMEs' Role in Propelling Economic Development of India \& A Discussion on Current HR Issues in MSMEs' in India, International Journal of Scientific \& Research Publications, Vol. 5, Issue 2, ISSN No. 2250 $-3153,2015$, pp $1-11$.

[9]. "MSMEs at a glance 2016", Ministry of Micro, Small and Medium Enterprises, New Delhi, 2016. 